\title{
The Impact of Technology upon Formal Communication: Texting Impacting the Standard English
}

\author{
NAZIA SULEMAN \\ Assistant Professor, Department of Humanities \\ COMSATS Institute of Information Technology Vehari Campus \\ UZMA SADIQ \\ English Department \\ University of Education, Dera Ghazi Khan Campus \\ SAFIA SIDDIQUI \\ English Department \\ Islamia University Bahwalpur
}

\begin{abstract}
With the invention of mobile phones text messaging has become a popular medium of communication. Its users are multiplying with every passing day. Its use is not only limited to informal but to formal communication as well. Students are the advent users of mobile phones and of SMS as well. The present study manifests the fact that students are practicing SMS for a number of reasons and a good amount of time is spent upon it which is resulting in typographical features, graphones and rebus writing. Data is collected through questionnaires and came to the conclusion that its effect is obvious in the L2 users in general and examinations in particular.
\end{abstract}

Keywords: Text messaging, technology, exams, formal writing.

\section{Introduction}

Human language get influenced much by the new technology particularly communication technology. The mobile phones with the special feature of texting are the modest way of communication in order to stay informed and connected with the friends and family as well as with the community. The texting refers to the brief message typed on the mobile phones for the sake of communication or transmission of message. SMS got life in 1990 it was firstly used at the eve of Christmas and since then it had grasped the attention of those who want to transmit the message in minimum time. It has been a tool of fastest and quickest communication; its users are being multiplied every day because of its easy and useable style. "Texts communicated by pagers were replaced by text messages, at first only twenty characters in length" (Crystal:2008). And although the first experimental messages were sent (in Finland) in 1992-3, it took five years or more before numbers of users started to build up. This slow start resolved many of the problems coming in its way and by 2001 according to Orange Magazine Nearly a billion text messages whizz around the UK every month. Whenever and however you like to send you text messages, it's a completely individual way to express yourself (Orange Magazine, Spring 2001). 


\subsection{Significance of the Study}

This study attempts to find out the detrimental effects of SMS language especially on the formal language of learners at the university level in Pakistan.

1.2 Research Question

The study addresses the following research questions in particular.

- What type of relationship obvious relationship exists in the frequency of texting and formal writings?

\subsection{Objectives of the study}

The purpose of this study is to figure out the time spent by the students on SMS and its impact on the formal written work that deviate from the Standard English which is normally taught in the public sector universities. The students are using the mobile phones frequently and are using it for the communication among friends and family so, its users are increasing with every passing minute. It's not only quick but also the cheap way of communication. The mother tongue of the users is different but the communicational language is graphones or English

\section{Literature Review}

In a very limited time (December, 1992 to 2012) text message language has aroused a great deal of interest amongst the scholars, teachers and parents to look for its possible impact upon the young generation. According to Gold stuck (2006) mobile phones were introduced to the youth market in the late 1990's. Thurlow (2011) studied the cell phone users, SMS character and its length and the factors behind text language which are making users to go for rebus writing, for short spellings and for other grammatical lapses. While Crystal (2008) is of the view that texting is a way to increase the literary skills of a particular language and also a way of practice which would ultimately increase the proficiency of a language. "Txtng the Gr8 Db8" by David Crystal is so far the most comprehensive work on SMS text language.

Despite of its numerous benefits, language researchers/linguists have found that the prolonged use of SMS has detrimental effects on the learners' language proficiency (Dansieh, 2011; Mphahlele \& Mashamaite, 2005; Ochonogor, Alakpodia \&Achugbue, 2012; Winzker, Southwood \& Huddlestone, 2009). These researchers believed that SMS language had greatly influenced the Standard English language use especially by the students because of its brevity and conciseness. It is in vogue because of its distinguishing features of easy and quick way of communication. In a very limited time (December, 1992 to 2012) text message language has aroused a great deal of interest amongst the scholars, teachers and parents to look for its possible impact upon the young generation. According to Gold stuck (2006) mobile phones were introduced to the youth market in the late 1990's. Thurlow (2011) studied the cell phone users, SMS character and its length and the factors behind text language which are making users to go for rebus writing, for short spellings and for other grammatical lapses. While Crystal (2008) is of the view that texting is a way to increase the literary skills of a particular language and also a way of practice which would ultimately increase the proficiency of a language. "Txtng the Gr8 Db8" by David Crystal is so far the most comprehensive work on SMS text language. 


\section{Population}

The participants were selected according to their language status and their level BS or Master. In total 90 questionnaires were collected back from BS level as well as Master classes all were L2 learners of English. Basic information was also collected in order to make it sure that all the participants are L2 users of English. The first two questions address the frequency and time spent upon texting. In the questionnaire, learners were also asked to specify three reasons for their use of texting. The motive behind asking this question was to get the information whether texting is used for communication, for chat, for information sharing, for entertainment, or to alleviate boredom. This information would be vital to trace the main motivational drive behind the use of SMS and would further lead to figure out the time spent upon cell phone usage.

\section{Data Analysis}

Excel spread sheet was used and all the answers to each question in the learners' questionnaires were tallied according to class, grade and language group. For the comprehensive overview of results graphs tables are used. Now I would discuss the questions one by one and the results will also be discussed in detail. First question asked from the students was about their mother language as we all know that in Pakistan English is the L2 not L1 so all of us are practicing it as L2 and learning it for the sake of communication and getting knowledge.

\begin{tabular}{|c|c|c|c|c|c|c|}
\hline \multirow{2}{*}{\multicolumn{7}{|c|}{ What is your mother language? }} \\
\hline & & & & & & \\
\hline Institution & $\begin{array}{l}\text { No. } \\
\text { Students }\end{array}$ & of & Saraiki & Punjabi & Urdu & Others \\
\hline $\begin{array}{l}\text { Islamia University } \\
\text { Bahawalpur (IUB) }\end{array}$ & 20 & & 12 & 4 & 2 & 2 \\
\hline University of & & & & & & \\
\hline $\begin{array}{l}\text { Education } \\
\text { (UoE) }\end{array}$ & 20 & & 4 & 13 & 1 & 2 \\
\hline University & & & & & & \\
\hline Agriculture & 30 & & 3 & 18 & 3 & 6 \\
\hline Faisalabad (UAF) & & & & & & \\
\hline COMSATS Vehari & 23 & & 3 & 14 & 3 & 3 \\
\hline
\end{tabular}

This table 1 is a summary about the number of students as well as about the languages which are used by them at home. Students who are L2 practitioners of a language are never expected to be at home in language as can be the native speakers of that language. As our maximum data collection is from Southern Punjab so the ratio of Punjabi speakers is quite higher as compared to other local languages. So, students who are coming from different languages, areas and backgrounds are the population and there is no one with English as L1 so all the targeted population is the L2 users of English Language. 
Table 2: Frequency of Using SMS

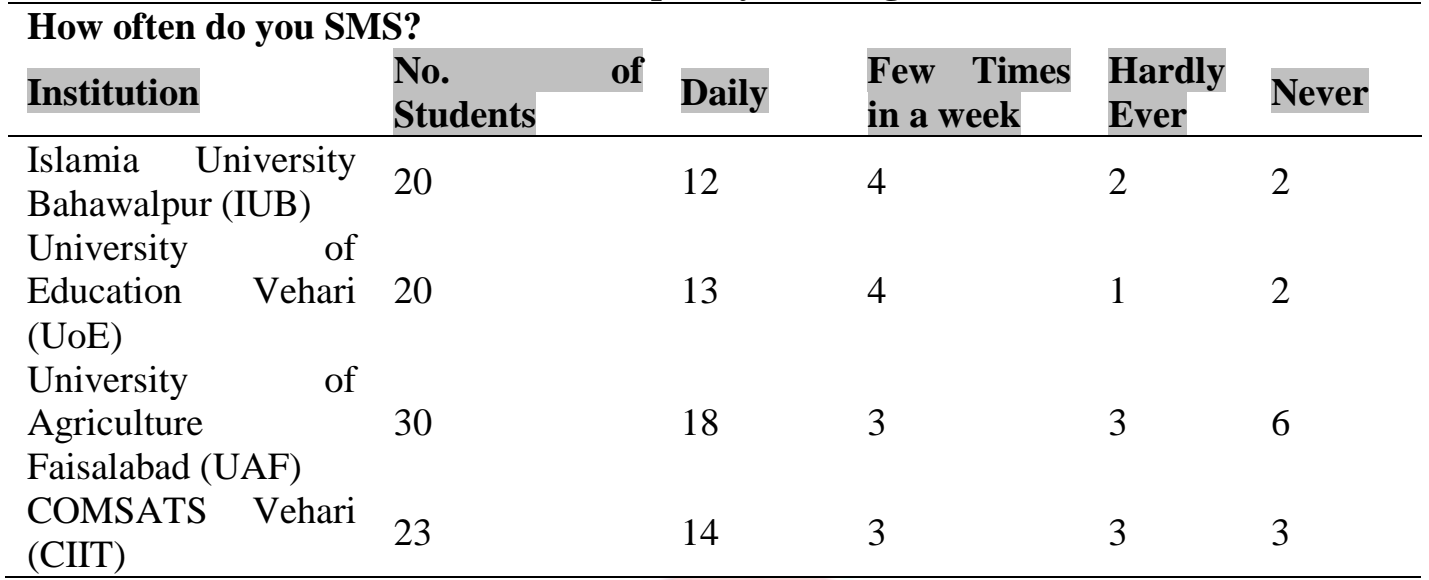

The results of the table supports the hypothesis that there are also few students who highlighted the point that they never use SMS in day but their ratio is lesser, daily users are more in no as compared with others. So it can be supportive figure to test hypothesis 1 that students in public sector universities are frequently using SMS and spent good no. of hours on SMS in order to get connected with society and circles of friends. There are couple of reasons highlighted by the many other researchers of the area that why SMS is getting so fame amongst the youngsters one of them is its easy and useable style, asynchronous mode of communication and the most important of all its cheap so it economical for the students. Frequency of SMS is manifestation of the fact that SMS service is really a blessing for the students who are specially in hostels and away from their near and dear ones.

Table 3: Time on SMS

How much time you spend on SMSing in a day?

\begin{tabular}{llllll} 
Institution & No. of Students & $\begin{array}{l}\text { 1 hour } \\
\text { or less }\end{array}$ & $\mathbf{2}$ hour & 3 hour & More \\
\hline $\begin{array}{l}\text { Islamia University } \\
\text { Bahawalpur (IUB) }\end{array}$ & 20 & 12 & 4 & 2 & 2 \\
$\begin{array}{l}\text { University of } \\
\begin{array}{l}\text { Education Vehari } \\
\text { UoE) }\end{array}\end{array}$ & 20 & 13 & 4 & 1 & 2 \\
$\begin{array}{l}\text { University } \\
\begin{array}{l}\text { Agriculture of } \\
\text { Faisalabad (UAF) }\end{array}\end{array}$ & 30 & 18 & 6 & 3 & 3 \\
$\begin{array}{l}\text { COMSATS Vehari } \\
\text { (CIIT) }\end{array}$ & 23 & 14 & 3 & 3 & 3 \\
\hline
\end{tabular}

The data collected from the survey designed to the fact that students have habits of cell phone usage so how it can be controlled as good no of hours are spent upon it as is manifested in the table. Approximately one hour of the day spent by all and the other figures do vary might be depending upon the need of students or reasons to communicate. A very astounding fact shows in the table supports the view that the students are even 
spending more than 03 hours upon SMS, which is quite a bigger figure with respect to the activity time of students. So, SMS is consuming quite a longer time from the schedule of the students and is encompassing their energies as well as time. According to the research cell phone usage is exceeding $90 \%$ in U.S and another study revealed the fact that youngsters are habitual of checking their cell phones at an average of 60 times per day and approximately send 3,200 text messages per month. Experts are of the view that cell phone usage has become a behavioral addiction like gambling, over-exercise and compulsive shopping.

Table 4: Reasons to Use SMS

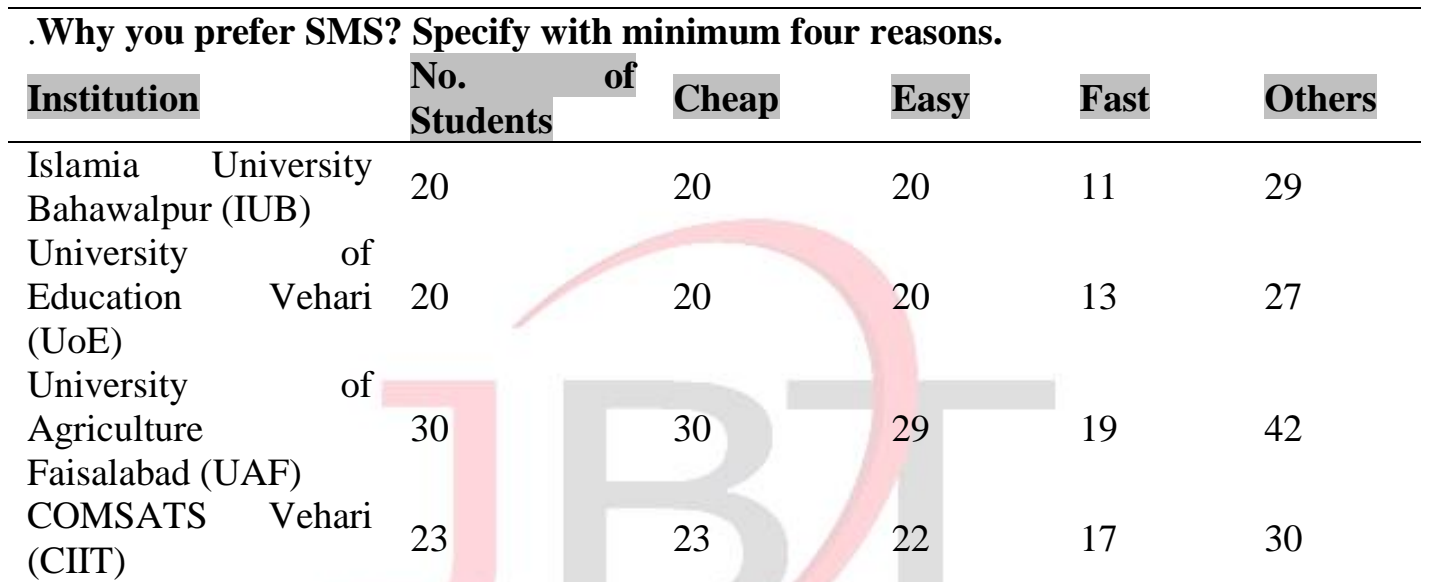

SMS is technological communication and being the quicker and fastest way is gaining popularity day by day and has engulfed a good no of users around the globe in its circle. Texting usage is hampering the formal writings as its being use excessively on daily basis. Every user is coming up with its own reason to use SMS but the most common to all is cheap and asynchronous mode of communication.The reason given for the SMS use indicates that learners are motivated to the SMS on regular basis. The data collected in the figure supports to the stance that learners are equally motivated to use SMS practice on the regular basis as well the reasons given for its usage is equally valid that its cheap as well as faster way makes it usage to increase day by day.

Table 5: Freedom to Use SMS

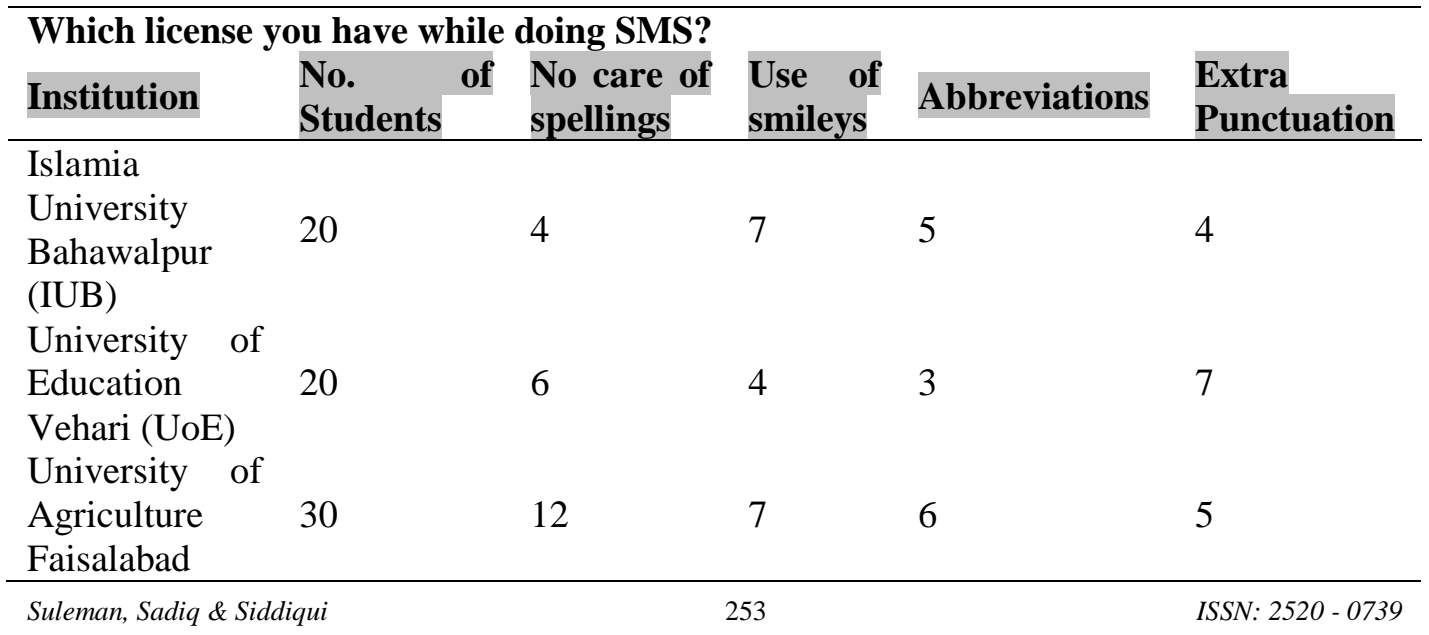




\section{(UAF)}

COMSATS

Vehari (CIIT)

23

11

5

4

3

In SMS practices it has been observed that students are using some features as well as some shortening, in order to calculate the frequency of its use care free areas which were bit deviant from the standard English were asked to which all agreed that they are using it in their SMS for the sake of communication.

The youngsters and teens are found to be very expressive so to convey expressions smileys and extra punctuation marks are used which are understandable to both ends.

The purpose of such usages is to convey the inner feelings and emotions so it should not look like the talk of an absent person but should be equally comprehendible to the receiver with all the possible feelings and emotions. Smileys express feelings and emotions and punctuation marks represent the emphasis placed upon the SMS at that time. Abbreviations are also a way to express longer talks into shorter ways so the maximum sharing can be possible with 160 characters of the cell phone.

Table 5: SMS and Formal Writing

\begin{tabular}{|c|c|c|c|}
\hline \multicolumn{4}{|c|}{ Do you think SMS affects formal writing the way you write in exams/assignment? } \\
\hline Institution & No. of Students & Spellings & Punctuation \\
\hline $\begin{array}{lll}\text { Islamia } & \text { University } & \text { Bahawalpur } \\
\text { (IUB) } & \end{array}$ & 20 & 13 & 7 \\
\hline $\begin{array}{l}\text { University of Education Vehari } \\
\text { (UoE) }\end{array}$ & 20 & 17 & 3 \\
\hline $\begin{array}{l}\text { University of Agriculture } \\
\text { Faisalabad (UAF) }\end{array}$ & 30 & 23 & 7 \\
\hline COMSATS Vehari (CIIT) & 23 & 17 & 6 \\
\hline
\end{tabular}

The core areas of the language where students are observed weaker are spellings and punctuation and maximum number of students agreed to the fact that due to the frequent use of SMS in their routine lives they have become habitual of practicing shorter spellings and abbreviations which is ultimately apparent in the formal writings as well.

It's an established fact that language is in always in the state of evolution, but the matter of concern for the educationists and linguists is this either it's a matter of language change or language decline. Parents and teachers opines upon it differently as they want to adhere themselves to the set standards of language while youngsters want to go the other way. The teachers normally do not tolerate the SMS practices in the writings of the students as it leads to distortion in an ability to express one eloquently, it hinders the way to use the words correctly and appropriately in the context. Students are committing such things unconsciously and are regular users of it which creates a no of problems while they are communicating formally. 
Table 6: Way of Writing in Exam

\begin{tabular}{llllll}
\hline $\begin{array}{l}\text { Do you think SMS affects formal writing } \\
\text { exams/assignment? }\end{array}$ & $\begin{array}{l}\text { the way you write in } \\
\text { Institution }\end{array}$ & No. of Students & Yes & No \\
\hline $\begin{array}{l}\text { Islamia University } \\
\text { (IUB) }\end{array}$ & Bahawalpur & 20 & 19 & 01 \\
$\begin{array}{l}\text { University of } \\
\begin{array}{l}\text { Vehari(UoE) Education } \\
\text { University of }\end{array}\end{array} \quad$ Agriculture & 30 & 18 & 02 \\
$\begin{array}{l}\text { Faisalabad (UAF) } \\
\text { COMSATS Vehari }\end{array}$ & 20 & 30 & 0 \\
\hline
\end{tabular}

All agreed to our central question is it affecting the formal writings or not? We got maximum results in the favor of this question which is under consideration. Supports the hypothesis that SMS is really corrupting the standards of English and as its users is multiplying on the daily basis so it's also going to prevail in the writings of the students. The formal writing is rule bound language and does observe certain rules and regulations to mantain the standards of the language but it is all missing in the texting which is the clear violation of the set rules. Being the regular users of SMS students are found that they do also practice texting in their formal writings which is a matter of concern not only for the language teachers but also for the linguists and parents. SMS practice has been called unique as it comprises the features of spoken as well as the written discourse.

\subsection{Graphical representation of the effect of SMS upon the Formal Writings}

The administration can go and look for the identified areas, highlighted by the students. Once an area is marked it can be improved and worked upon by constant monitoring and observation. Special sessions can be arranged to brief the students about the possible consequences of a practice. The above results go in line with the hypothesis 05 that administration has been able to pin point the areas of attention. Researcher have observed that even before the practice of SMS usage Pakistani students who are using English as L2 are weaker in spellings as this language is not taught with its all necessity but is taught just for the sake of getting through the exams so SMS service cannot be only blamed for the reason of miss spell and wrong use of punctuation marks. Administration of schools and colleges should must take preliminary steps to combat the practices of SMS speak in the formal writings but on the other hand an understanding of learning and mastering the language is also the need of time.

\section{Conclusion}

These results support the stance that text messaging is used for the good no. of hours by the students as the students and youngsters are the frequent users of it so they are employing the features of SMS in their exams as well. On one hand, it is increasing their vocabulary while on the other it is increasing the interaction with the language as well. Thurlow (2003) observes that young people are the driving forces behind a growing text messaging culture. Youngsters are adopting the above mentioned deviations, are the advent users of this language. An excessive use of texting is affecting the formal writing and becomes dominant at times because of its shortening. Crystal (2004) is of the view that students who have the knowledge of the English language are practicing abbreviations and acronyms just for comfort and ease of communication. The use of 
mother tongue on texting can also be worked upon to measure the effects upon the L2. The features of local languages are also evidently been practiced by the users in texting.

\section{References}

Baron, N. (1984). Computer Mediated Communication as a force in language change. Visible Language XVIII (1): 118-41.

Baron, N. (2000).Alphabet to Email: How written English evolved and where it's heading.New York: Routledge..

Crystal, D. (2001). Language and the Internet. United Kingdom: Cambridge University Press.

Crystal, D. (2004). The Language Revolution. United Kingdom: Polity Press Ltd..

Herring, (1996). Introduction to Computer Meditated Communication, Linguistics, social and cross cultural perspective (pp1-10)Amsterdam:Benjamins.

Igarashi, T., Motoyoshi, T., Takai, J., \& Yoshida, T. (2008). No mobile, no life: selfperception and text-message dependency among Japanese high school.

Thurlow, C. (2003). Generation Txt? Exposing the sociolinguistics of young people's text messaging. Available online at: http://extra.shu.ac.uk/daol/articles/v1/n1/a3/thurlow2002003-paper. Accessed on 31st March 2008.

Thurlow, C., Lengel, L. \& Tomic, A. (2004).Computer mediated communication: Social interaction and the Internet, London: Sage Publications Ltd.

Werry, C. (1996). Linguistic and interactional features of Internet Relay Chat.In Herring,S.C. (ed.) Computer-Mediated Communication.Linguistic, social and crosscultural perspectives (pp. 47-61). Amsterdam: Benjamins. 